\title{
Excess ice loads in the Indian Ocean sector of East Antarctica during the last glacial period
}

Ishiwa. T., Okuno, J., Suganuma, Y.

\section{Supplementary Information}

\section{DETAILED METHOD OF GLACIAL ISOSTATIC ADJUSTMENT MODELING}

The GIA model calculates past sea levels including the solid Earth's deformation theoretically caused by surface loading changes (e.g., Farrell and Clark, 1976). We used a GIA model (Okuno and Nakada, 1999; Ishiwa et al., 2019) to calculate sea-level predictions for the study sites, incorporating the Earth's rotational feedback (Milne and Mitrovica, 1998), shoreline migration (e.g., Johnston, 1993), and gravitational attraction between the ice sheets and the ocean (e.g., Nakada and Lambeck, 1989). The modern topography in the GIA model is based on Bedmap 2 (Fretwell et al., 2013) in the southern high-latitudinal region $\left(61^{\circ}-90^{\circ} \mathrm{S}\right)$ and ETOPO dataset (Amante and Eakins, 2009) in the remaining area; the data for both regions have a $5 \mathrm{~min}$ resolution. We conducted sensitivity tests for the Earth models (Figure S1) and set a $100 \mathrm{~km}$ elastic lithosphere, an upper mantle viscosity of $1 \times 10^{21} \mathrm{~Pa}$ s, and a lower mantle viscosity of 7 $\times 10^{22} \mathrm{~Pa} \mathrm{~s}$.

Excess ice loads on the specific regions (Antarctic Drainage System 7-12 and 4-12; Rignot et al., 2011) were incorporated to check the impact of scaling on the GIA predictions (Figure S2). The difference in predictions induced by excess ice loads on Antarctic Drainage System 7-12 and 4-12 is not significantly large (Figure S2), and the MIS 3 observation is not obtained in Antarctic Drainage System 4-6 regions. Accordingly, we applied the excess ice loads on Antarctic Drainage System 7-12. The sensitivity test to scaling ice loading (multiply by $1.5,2.0$, and 2.5 ) indicates that increasing ice load achieves shallower predictions (Figure S3) and thus we used a $\times 2.0$ load as a representative value. Reduction of the Laurentide Ice Sheet during the glacial period has been reported (Pico et al., 2018; Dalton et al., 2019), so we also tested the effect of scaling northern hemisphere ice sheet loading (Figure S4). The results indicate that the refined ice loading history in East Antarctica should be considered in order to reproduce the observed sea level in the study area with the GIA modeling. 

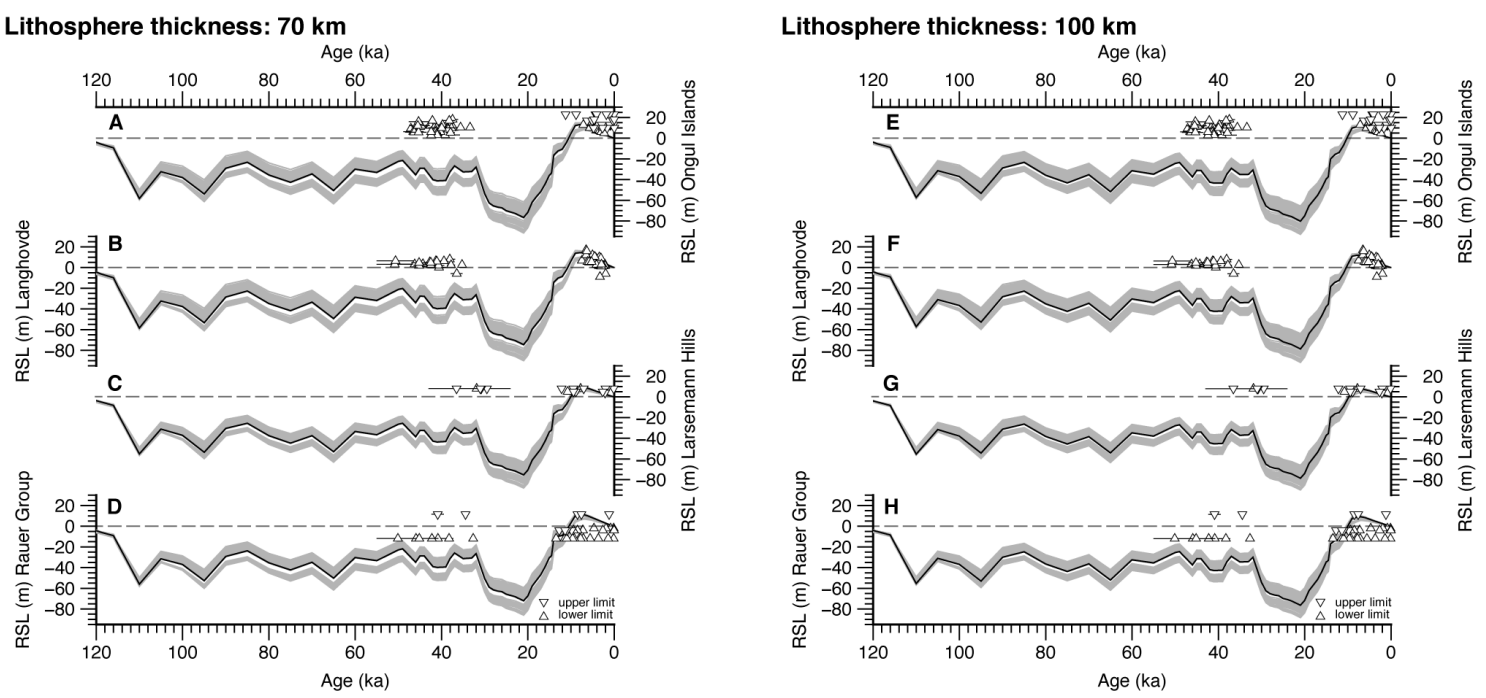

Figure S1. The sensitivity test results of Earth models. Upper mantle viscosity of $(0.8-2) \times$ $10^{21} \mathrm{~Pa} \mathrm{~s}$, and lower mantle viscosity of $(0.1-10) \times 10^{22} \mathrm{~Pa} \mathrm{~s}$. The range of upper mantle viscosity is referred from Whitehouse et al. (2012a, b). The left column is a 70-km elastic lithosphere, and the right column is a 100-km elastic lithosphere. The ice history of northern hemisphere and Antarctica is ANU model (Lambeck and Chapperll, 2001; Lambeck et al., 2010, 2014), and W12 model (Whitehouse et al.,2012a, b), respectively. The observations and predictions of (A, E) the Ongul Islands, (B, F) Langhovde, (C, G) Larsemann Hills, and (D, H) the Rauer Group. Upward and downward triangles represent lower and upper limits of sea level, respectively. 

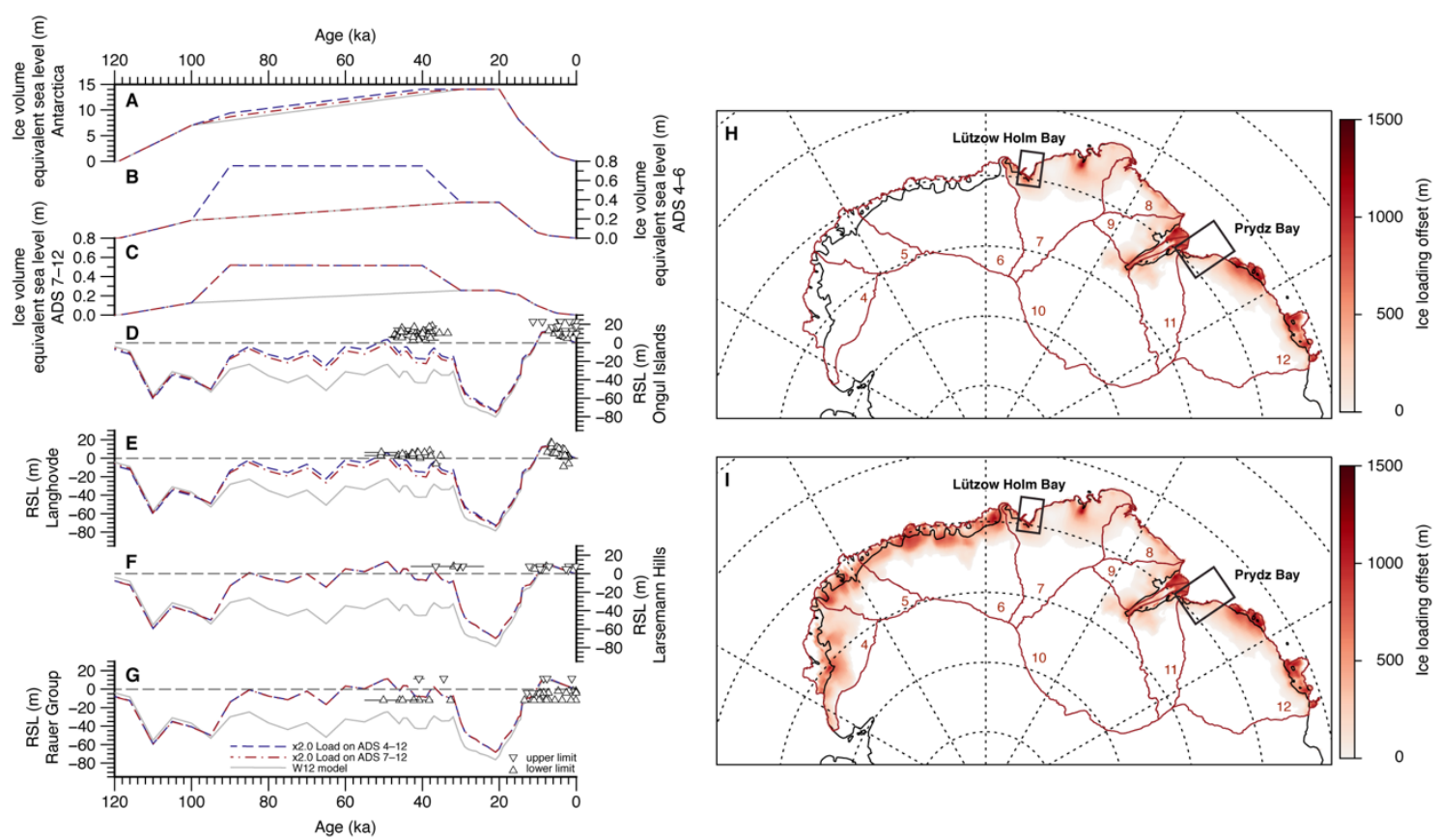

Figure S2. The sensitivity test to the different regions of excess ice loads. Ice loading

histories and sea-level predictions of excess ice loads on Antarctic Drainage System 4-12 are blue lines, these of Antarctic Drainage System 7-12 are red lines, and these of W12 model are gray lines. Ice-volume equivalent sea levels of (A) Antarctica, (B) Antarctic Drainage System 4-6, and (C) Antarctic Drainage System 7-12 regions. The observations and predictions of (D) the Ongul Islands, (E) Langhovde, (F) Larsemann Hills, and (G) the Rauer Group. Upward and downward triangles represent lower and upper limits of sea level, respectively. The offset of ice loading at $40 \mathrm{ka}$ with the W12 model (Whitehouse et al., 2012a, b) and excess ice loads on Antarctic Drainage System (H) 7-12 and (I) 4-12. Excess ice loads were set to $\times 2.0$ value at the 20-ka status for the positive ice loading area. 

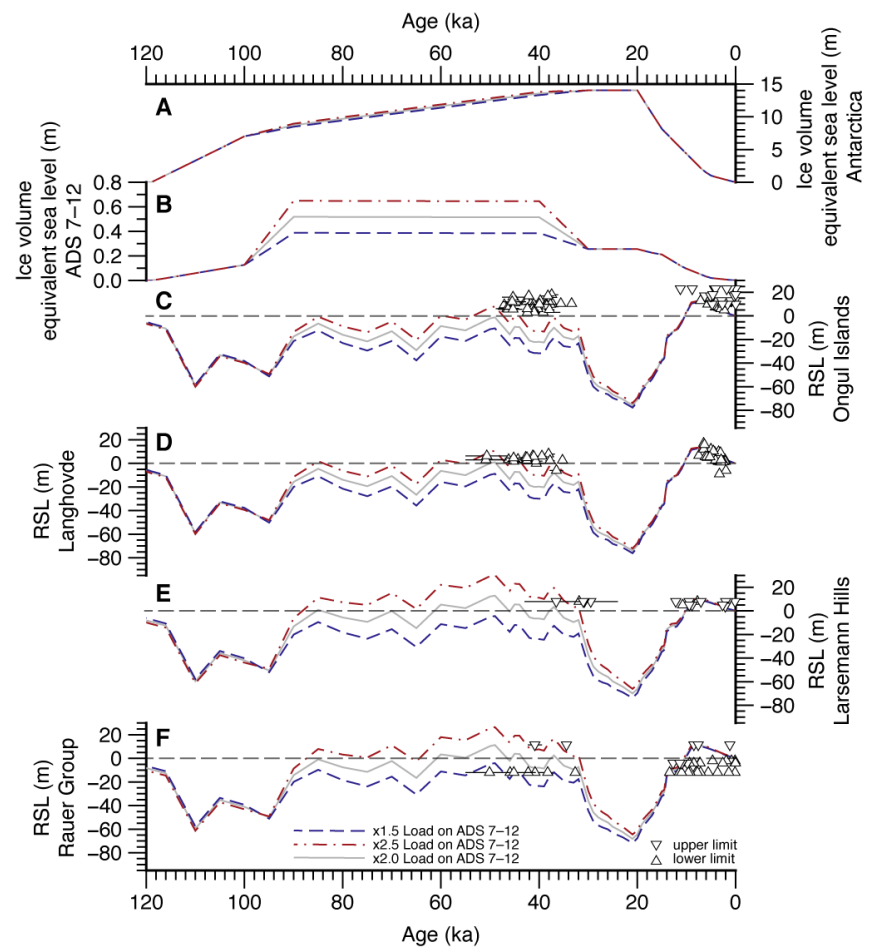

Figure S3. The sensitivity test to the different excess ice loads amplitude. Ice loading histories and sea-level predictions of $\times 1.5$ excess ice loads on Antarctic Drainage System 7-12 are blue lines, these of $\times 2.5$ excess ice loads are red lines, and $\times 2.0$ excess ice loads are gray lines. Ice-volume equivalent sea levels of (A) Antarctica and (B) Antarctic Drainage System $7-$ 12 region. The observations and predictions of (C) the Ongul Islands, (D) Langhovde, (E) Larsemann Hills, and (F) the Rauer Group. Upward and downward triangles represent lower and upper limits of sea level, respectively. The result indicates that more ice loads on Antarctic Drainage System 7-12 region reveals higher predictions during MIS 3 (57-29 cal kyr BP). In this study, a $\times 2.0$ value is used as a representative scaling value. 


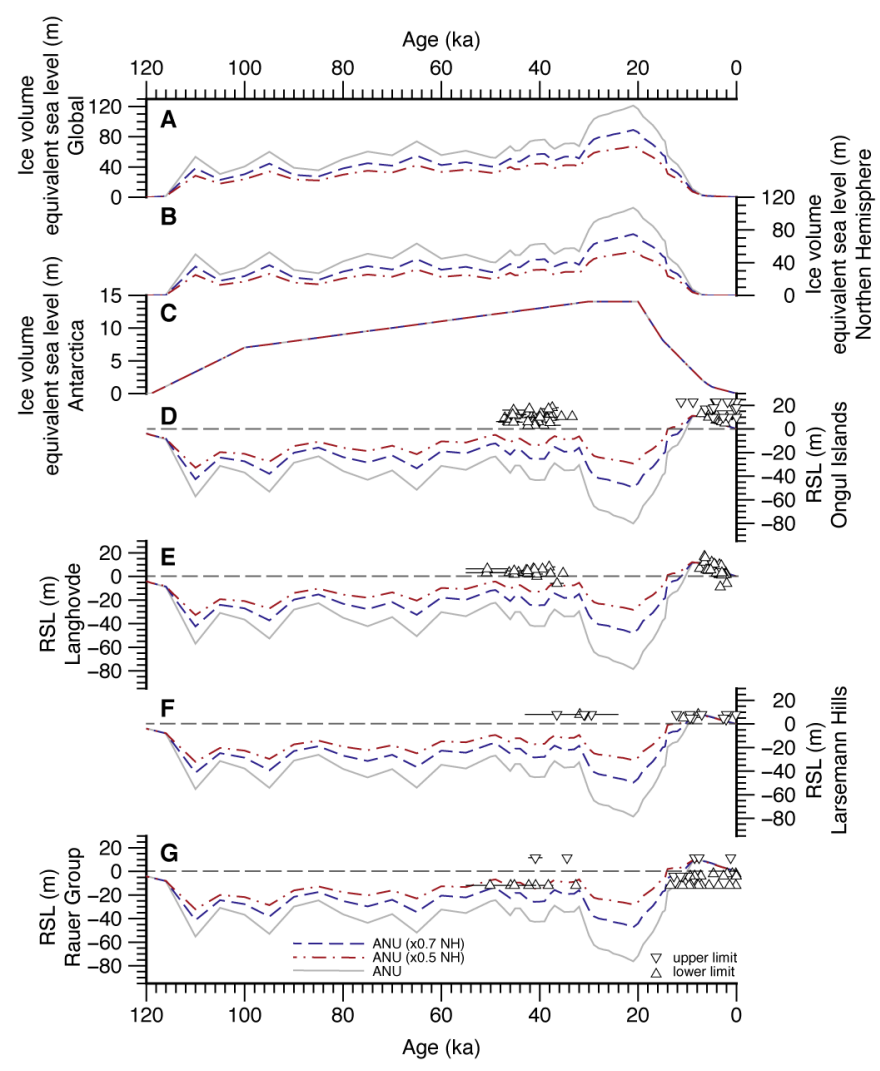

Figure S4. The sensitivity tests to the different northern hemisphere ice sheet volumes. Ice loading histories and sea-level predictions of $\times 0.7$ northern hemisphere ice sheet volumes are blue lines, these of $\times 0.5$ northern hemisphere ice sheet volumes are red lines, and the original ANU model are gray lines. (A) Ice loading history of ANU model in the northern hemisphere. The loading amplitude multiplied by 0.5 and 0.7. Pico et al. (2018) estimated the MIS 3 global sea level reached $-40 \mathrm{~m}$ during MIS 3, corresponding to the combined model of W12 + ANU ( $\times 0.5$ ). (B) Ice loading history of W12 model (Whitehouse et al., 2012a, b). The observations and predictions of (D) the Ongul Islands, (E) Langhovde, (F) Larsemann Hills, and (G) the Rauer Group. Upward and downward triangles represent lower and upper limits of sea level, respectively.

\section{REFERENCE}

Amante, C., and Eakins, B.W., 2009, ETOPO1 1 Arc-Minute Global Relief Model: Procedures,

Data Sources and Analysis: NOAA Technical Memorandum NESDIS, NGDC-24, 19 pp.

Dalton, A.S., Finkelstein, S.A., Forman, S.L., Barnett, P.J., Pico, T., and Mitrovica, J.X., 2019,

Was the Laurentide Ice Sheet significantly reduced during Marine Isotope Stage 3?:

Geology, v. 47, p. 111-114, doi: 10.1130/G45335.1.

Farrell, W.E., and Clark, J.A., 1976, On Postglacial Sea Level: Geophysical Journal of the Royal Astronomical Society, v. 46, p. 647-667. 
Fretwell, P., Pritchard, H.D., Vaughan, D.G., Bamber, J.L., Barrand, N.E., Bell, R., Bianchi, C., Bingham, R.G., Blankenship, D.D., Casassa, G., Catania, G., Callens, D., Conway, H., Cook, A.J., Corr, H.F.J., Damaske, D., Damm, V., Ferraccioli, F., Forsberg, R., Fujita, S., Gim, Y., Gogineni, P., Griggs, J.A., Hindmarsh, R.C.A., Holmlund, P., Holt, J.W., Jacobel, R.W., Jenkins, A., Jokat, W., Jordan, T., King, E.C., Kohler, J., Krabill, W., Riger-Kusk, M., Langley, K.A., Leitchenkov, G., Leushen, C., Luyendyk, B.P., Matsuoka, K., Mouginot, J., Nitsche F.O., Nogi, Y., Nost, O.A., Popov, S.V., Rignot, E., Rippin, D.M., Rivera, A., Roberts, J., Ross, N., Siegert, M.J., Smith, A.M., Steinhage, D., Studinger, M., Sun, B., Tinto, B.K., Welch, B.C., Wilson, D., Young, D.A., Xiangbin, C., and Zrizzotti, A., 2013, Bedmap2: improved ice bed, surface and thickness datasets for Antarctica: The Cryosphere, v. 7, p. 375-393, doi: 10.5194/tc-7-375-2013.

Ishiwa, T., Yokoyama, Y., Okuno, J., Obrochta, S., Uehara, K., Ikehara, M., and Miyairi, Y., 2019, A sea-level plateau preceding the Marine Isotope Stage 2 minima revealed by Australian sediments: Scientific Reports, v. 9, p. 1-8, doi: 10.1038/s41598-019-42573-4. Johonston, P., 1993, The effect of spatially non-uniform water loads on prediction of sea- level change: Geophysical Journal International, v. 114, p. 615-634, doi: 10.1111/j.1365246X.1993.tb06992.x.

Lambeck, K., and Chappell, J. 2001, Sea Level Change Through the Last Glacial Cycle: Science 292, 679-686, doi: 10.1126/science.1059549

Lambeck, K., Purcell, A., Zhao, J., and Svensson, N., 2010, The Scandinavian Ice Sheet: from MIS 4 to the end of the Last Glacial Maximum: Boreas 39(2), 410-435, https://dx.doi.org/10.1111/j.1502-3885.2010.00140.x

Lambeck, K., Rouby, H., Purcell, A., Sun, Y., and Sambridge, M., 2014, Sea level and global ice volumes from the Last Glacial Maximum to the Holocene: Proceedings of the National Academy of Sciences, v. 111, p. 15296-15303, doi: 10.1073/pnas.1411762111.

Milne, G.A., and Mitrovica, J.X., 1998, Postglacial sea-level change on a rotating Earth: Geophysical Journal International, v. 133, p. 1-19, doi: 10.1046/j.1365246X.1998.1331455.x.

Nakada, M., and Lambeck, K., 1989, Late Pleistocene and Holocene sea-level change in the Australian region and mantle rheology: Geophysical Journal, v. 96, p. 497-517, doi: 10.1111/j.1365-246X.1989.tb06010.x.

Okuno, J., and Nakada, M., 2001, Effects of water load on geophysical signals due to glacial rebound and implications for mantle viscosity: Earth, Planets and Space, v. 53, p. 1121- 
1135, doi: 10.1186/BF03352408.

Pico, T., Birch, L., Weisenberg, J., and Mitrovica, J.X., 2018, Refining the Laurentide Ice Sheet at Marine Isotope Stage 3: A data-based approach combining glacial isostatic simulations with a dynamic ice model: Quaternary Science Reviews, v. 195, p. 171-179, doi: 10.1016/j.quascirev.2018.07.023.

Rignot, E., Mouginot, J., and Scheuchl, B., 2011, Ice flow of the Antarctic ice sheet: Science, v. 333, p. 1427-1430, doi: 10.1126/science. 1207922

Whitehouse, P.L., Bentley, M.J., and Le Brocq, A.M., 2012a, A deglacial model for Antarctica: geological constraints and glaciological modelling as a basis for a new model of Antarctic glacial isostatic adjustment: Quaternary Science Reviews, v. 32, p. 1-24, doi: 10.1016/j.quascirev.2011.11.016.

Whitehouse, P.L., Bentley, M.J., Milne, G.A., King, M.A., and Thomas, I.D., 2012b, A new glacial isostatic adjustment model for Antarctica: calibrated and tested using observations of relative sea-level change and present-day uplift rates: Geophysical Journal International, v. 190, p. 1464-1482, doi: 10.1111/j.1365-246X.2012.05557.x 